\title{
Deep Vein Thrombosis in the Setting of Neurofibromatosis Type 1: Case Report
}

\section{Trombose venosa profunda em neurofibromatose tipo 1: Relato de caso}

\author{
Fernando Guedes ${ }^{1(10}$ Francisco Torrão ${ }^{10}$ Gabriel E. Sanches ${ }^{10}$ Ana Caroline Siquara-de-Sousa ${ }^{2}$ \\ Arno von Ristow ${ }^{3(0)}$ Paulo Niemeyer Filho ${ }^{4}$
}

${ }^{1}$ Department of Surgery, Division of Neurosurgery, Hospital Universitário Gaffrée e Guinle, Escola de Medicina e Cirurgia, Universidade Federal do Estado do Rio de Janeiro (Unirio), Rio de Janeiro, Brazil

2 Department of Pathology, Hospital Universitário Antônio Pedro, Faculdade de Medicina, Universidade Federal Fluminense (UFF), Niterói, Brazil

${ }^{3}$ Vascular and Endovascular Surgery, Pontifícia Universidade Católica do Rio de Janeiro, (PUC-Rio), Rio de Janeiro, Brazil

${ }^{4}$ Department of Neurosurgery, Instituto Estadual do Cérebro Paulo Niemeyer, Rio de Janeiro, Brazil

Arq Bras Neurocir 2021;40(1):107-112.

\begin{abstract}
Address for correspondence Fernando Guedes, MD PhD, Divisão de Neurocirurgia, Hospital Universitário Gaffrée e Guinle, Escola de Medicina e Cirurgia, Universidade Federal do Estado do Rio de Janeiro (Unirio), Rua Mariz e Barros, 775, Rio de Janeiro, RJ, 20270-901, Brazil (e-mail: neuroguedes@yahoo.com.br).
\end{abstract}

\begin{abstract}
Keywords

- neurofibromatosis 1

- neurofibroma

- venous thrombosis

Neurofibromatosis type 1 (NF1) is a genetic syndrome which typically presents with neurological manifestations. Some of the patients may also present with vasculopathies, among which arterial aneurysms and stenosis are the most common. Deep vein thrombosis (DVT) has rarely been described, and, to the best of our knowledge, the present is the first report of DVT due to venous compression by a neurofibroma in the setting of NF1.

This is the case of a 23-year-old male with NF1 who experienced DVT due to compression of the left posterior tibial veins by a large tumor arising from the tibial nerve. The DVT was acutely treated with enoxaparin and then with rivaroxaban. Two months after the diagnosis, Doppler ultrasonography showed partial recanalization and persistence of the DVT. The patient was then referred to neurosurgery for surgical resection of the tumor. There were no complications during the procedure, and the patient did not present postoperative neurological deficits. The final histopathological diagnosis was of a benign neurofibroma. After one year of follow-up with vascular surgery, the patient presented no more episodes of DVT.

In case there is a tumor compressing the deep vessels of the leg and promoting DVT, surgical resection with microsurgical techniques may be curative.
\end{abstract}

received

August 19, 2020

accepted

November 16, 2020

published online

January 18, 2021
DOI https://doi.org/

$10.1055 / \mathrm{s}-0040-1722244$. ISSN 0103-5355.

\footnotetext{
(c) 2021. Sociedade Brasileira de Neurocirurgia. All rights reserved. This is an open access article published by Thieme under the terms of the Creative Commons Attribution-NonDerivative-NonCommercial-License, permitting copying and reproduction so long as the original work is given appropriate credit. Contents may not be used for commercial purposes, or adapted, remixed, transformed or built upon. (https://creativecommons.org/ licenses/by-nc-nd/4.0/)

Thieme Revinter Publicações Ltda., Rua do Matoso 170, Rio de Janeiro, RJ, CEP 20270-135, Brazil
} 


\section{Resumo}

\section{Palavras-chave \\ - neurofibromatose 1 \\ - neurofibroma \\ - trombose venosa}

A neurofibromatose tipo 1 (NF1) é uma síndrome genética classicamente associada a manifestações neurológicas. Contudo, alguns dos pacientes apresentam também manifestações vasculares, dentre as quais aneurismas e estenoses arteriais são as mais comuns. Trombose venosa profunda (TVP) associada a NF1 raramente foi descrita, e, pelo que sabemos, este é o primeiro relato de TVP devido a compressão venosa por neurofibroma no contexto de NF1.

Este é o caso de um paciente masculino de 23 anos, com NF1, que apresentou um episódio de TVP devido a compressão das veias tibiais posteriores esquerdas por um grande neurofibroma que surgia do nervo tibial. A TVP foi tratada de forma aguda, com enoxaparina e rivaroxabana. Dois meses após o diagnóstico, a ultrassonografia com Doppler demonstrou recanalização parcial com persistência da TVP. O paciente foi então referido à neurocirurgia para ressecção da massa. Não houve complicações devido ao procedimento, e o paciente não apresentou déficits neurológicos. O diagnóstico histopatológico final foi de um neurofibroma. Após um ano de seguimento com a cirurgia vascular, o paciente não apresentou mais episódios de TVP. Caso haja um tumor comprimindo os vasos profundos da perna e promovendo TVP, a ressecção cirúrgica com técnicas microcirúrgicas pode ser curativa.

\section{Background}

Neurofibromatosis type 1 (NF1) is a complex genetic syndrome, in which the gene for neurofibromin (a tumor suppressor protein) suffers a wide range of mutations, ${ }^{1}$ resulting in decreased neurofibromin synthesis. The prevalence of NF1 is around $1 / 3,000,2,3$ and it presents as a systemic disease, with dermatological, cardiovascular, gastrointestinal, orthopedic, central, and peripheral nervous system manifestations. ${ }^{4,5}$ One of the cardinal features of NF1 is the predisposition toward the development of certain peripheral nerve sheath tumors (PNSTs). These may be benign, such as neurofibroma, or malignant, such as the malignant peripheral nerve tissue tumor (MPNST). ${ }^{1}$ Among the systemic complications of NF1, there is a series of vascular abnormalities, of which arterial manifestations are the most common. Those mostly comprise aneurysms and stenoses of renal, aortic, and mesenteric arteries, ${ }^{6}$ with hypertension as the most common clinical feature secondary to these. ${ }^{4,6,7}$ Venous manifestations are, in turn, exceedingly rare, and may include venous thrombosis $(\mathrm{VT}){ }^{8-13}$

\section{Literature Search}

To investigate previous cases of NF1 with VT, we searched the MEDLINE database for articles written in English with the following MesH keywords and Boolean operators: ("Neurofibromatosis 1"AND "Venous thrombosis") OR ("Neurofibromatosis 1" AND "Vascular disease" AND "Vein"). While applying articletype filters to select case reports, clinical studies, observational studies, reviews, and systematic reviews, the search yielded 29 individual results, all case reports. In total, there were six case reports of NF1-associated VT. ${ }^{9-12,14,15}$ By searching the references of each of these studies, we were able to find another case. ${ }^{8}$ In these reports, five patients had aneurysms correlated to the formation of thrombus ${ }^{9,11,12,14,15}$ and two did not, ${ }^{8,10}$ one of which was secondary to compression by an exostosis. ${ }^{10}$
The other 23 articles reported arterial manifestations, vascular malformations, and NF1-associated vascular retinopathy. Some of these cases also presented with venous manifestations, ${ }^{13,16-23}$ yet none with thrombosis.

\section{Case Presentation}

\section{History and Examination}

One year before surgery, a 22-year-old male with NF1 presented with swelling on the left leg, accompanied by pain on walking. Doppler ultrasonography (USG) was performed and showed a large mass over the course of the left tibial nerve. There was no DVT, and the left saphenous veins were tortuous. We decided not to resect the tumor at that moment. The patient was treated with $0.5 \mathrm{~g}$ of metamizole twice a day for 1 week, with improvement of the pain.

Ten months later, the patient presented with an acute episode of edema and pain in the left leg. Doppler USG was performed, and showed DVT of the posterior tibial veins and thrombophlebitis of one collateral of the saphenous vein. The patient was hospitalized for 3 days, and underwent treatment with enoxaparin $(1.5 \mathrm{mg} / \mathrm{kg}$ once a day). A computed tomography angiogram (angio-CT) was performed, and it showed compression of the left fibular and posterior tibial veins by a large tumor arising from the tibial nerve ( - Fig. 1). Given the setting of NF1, the lesion was presumed to be a neurofibroma. The patient continued treatment with $15 \mathrm{mg}$ of rivaroxaban twice a day for 21 days, and then $20 \mathrm{mg}$ once a day. Doppler USG was again performed two months after the initial diagnosis of DVT, and it showed partial recanalization with persistence of a thrombus (-Fig. 2). The saphenous veins were congested and tortuous. The patient was then referred to the authors' care for evaluation by vascular and peripheral nerve surgery.

Upon physical examination, he presented with pain on the left leg (visual analog scale [VAS] =6), M4+ left foot flexion on the British Medical Research Council (BMRC) scale, and 

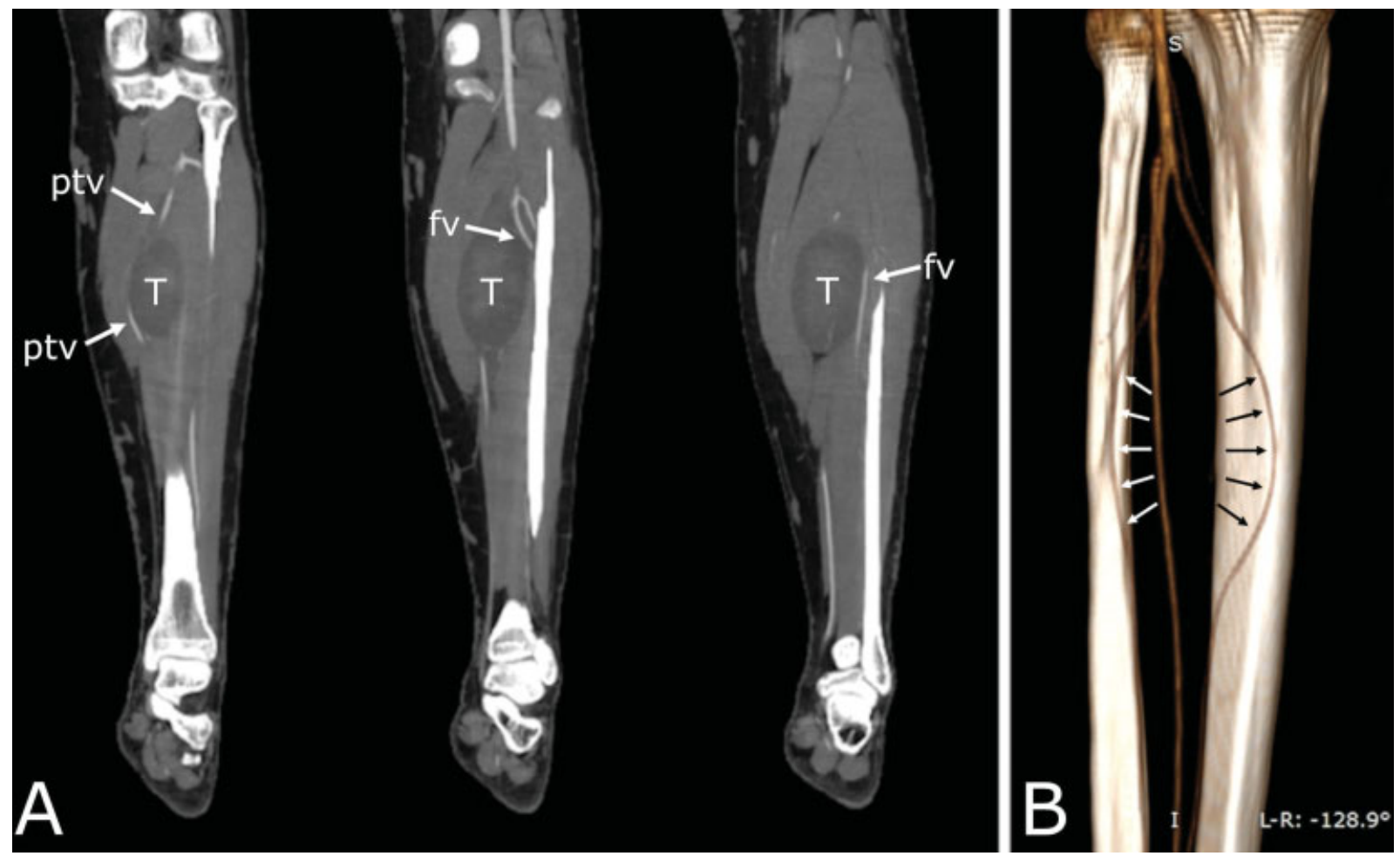

Fig. 1 (A) Three coronal slices of a computed tomography angiogram (angio-CT) showing the compression of the posterior tibial veins by the tumor ( $T$ ) arising from the tibial nerve. Note the deviation of the course of one of the posterior tibial veins (ptv), compressed against the muscles of the posterior compartment of the leg. One of the fibular veins ( $\mathrm{fv}$ ) appears to be compressed against the fibula. (B) 3D reconstruction of an angio-CT from a posterior-medial point of view showing the mass effect of the tumor onto the posterior tibial veins. The white arrows show one of the deviated fibular veins. The black arrows show one of the deviated posterior tibial veins.

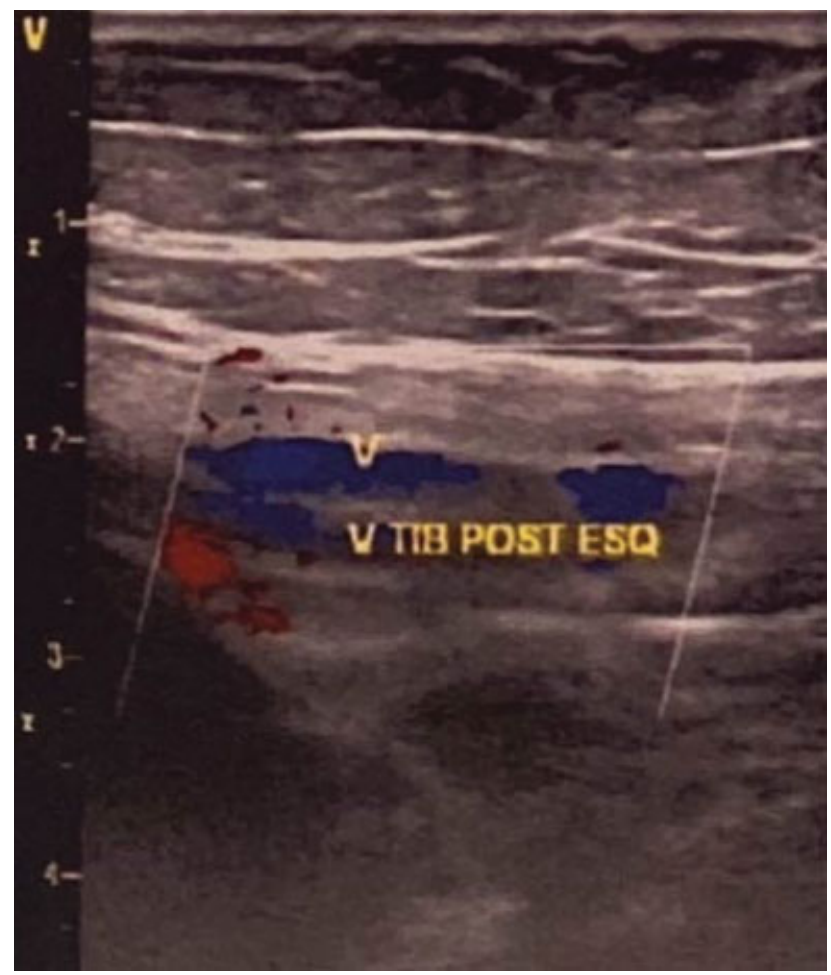

Fig. 2 Doppler ultrasonography of the left posterior tibial veins, performed two months after hospitalization for the treatment of deep vein thrombosis. There is partial recanalization, yet the thrombus is still present. Abbreviation: V TIB POST ESQ, left posterior tibial veins. plantar hypesthesia. The mass was not palpable, yet the left leg was edematous. There was also a positive Tinel sign over the course of the left tibial nerve.

Electroneuromyography was performed, and it showed a delay in motor conduction with a reduction of amplitude $(3.7 \mu \mathrm{V})$, and a minor delay in the distal sensitive response of the left sural nerve. Magnetic resonance imaging (MRI) was then also performed to better evaluate the tumor's relationship to neighboring structures and to help in the preoperative planning (- Fig. 3). Even though the lesion was large $(96 \mathrm{~mm}$ on its largest axis), it presented predominantly high $\left(>1.3 \times 10^{-3} \mathrm{~mm} / \mathrm{s}^{2}\right.$ ) apparent diffusion coefficient (ADC) values on diffusion-weighted imaging (DWI). This, along with the absence of features suggestive of malignancy (that is, peripheral enhancement, perilesional edema, intratumoral cystic changes), favored the hypothesis of a benign neurofibroma. ${ }^{24,25}$ There were no signs of muscle denervation.

\section{Surgery}

Given the presence of a large tumor inside the left tibial nerve, and the evidence of the persistence of DVT on Doppler USG, surgical resection of the tumor with decompression of the vessels was then decided. With the aid of loupes, a classic approach to the left tibial nerve through the medial aspect of the leg was performed, with mobilization of the gastrocnemius and soleus muscles. Gentle progressive dissection was then performed, with individualization of the compressed deep 

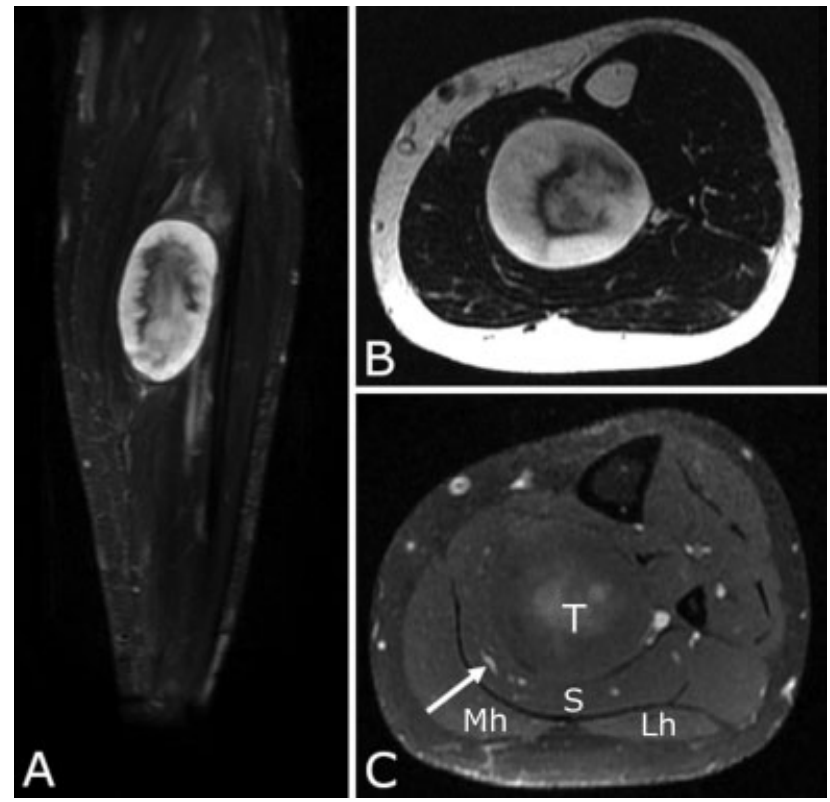

Fig. 3 (A) Coronal Short tau inversion recovery weighted (STIRweighted) magnetic resonance imaging (MRI) without contrast of a large heterogeneous lesion $(96 \times 56 \times 49 \mathrm{~mm})$ arising from the left tibial nerve and compressing the deep vessels of the posterior compartment of the left leg. The lesion presents with well-defined borders, and there are no apparent signs of tissue invasion or perilesional edema. (B) Axial T2-weighted MRI without contrast of the lesion showing predominantly high signal intensity and a central region with lower signal intensity. (C) T1-weighted MRI with contrast showing discrete and heterogeneous central enhancement. The arrow shows one of the posterior tibial veins compressed against the soleus muscle fascia. Abbreviations: Lh, lateral head of the gastrocnemius; Mh, medial head of the gastrocnemius; MRI, magnetic resonance imaging; S, soleus muscle; T, tumor. vessels of the leg. After the complete exposure of the tumor (and of the healthy tibial nerve proximally and distally to the mass), electrical mapping of its surface was conducted with the aid of intraoperative electrical stimulation to identify an area devoid of functional fascicles. With the aid of microsurgical techniques under microscopy, a sharp opening of the pseudotumoral capsule was performed in this "electrically-silent" area. An intraoperative biopsy was then performed, and it revealed a probable neurofibroma, without characteristics of malignancy. The pseudotumoral capsule could be differentiated from the true tumor capsule by its color and consistency (respectively white-grayish and tough, against yellowish and soft), and a cleavage plane was established in a fascicle-free corridor. A circumferential dissection was performed with complete isolation of the tumor toward its proximal and distal poles to identify the tumor's fascicle of origin (in this case, only one). The fascicles that entered and exited the tumor were not functional, and they were sectioned. The huge tumoral mass was resected en bloc, with the preservation of the functional fascicles. The borders of the nerve were gently everted to look for any residual tumor inside the nerve ("open book" maneuver) (-Fig. 4).

\section{Follow-up}

No postoperative complications were observed. The patient left the hospital with the same deficit as before (M4+ foot flexion) and reduction of pain (VAS $=3$ ). He was treated with pregabalin as soon as was discharged $(75 \mathrm{mg} 3$ times a day during the first month; twice, during the second month; and once, during the third month), and was directed to physiotherapy treatment after the stitches were removed. He was followed up in the outpatient clinic, and, after 3 months, recovered to M5 foot flexion and presented with no more

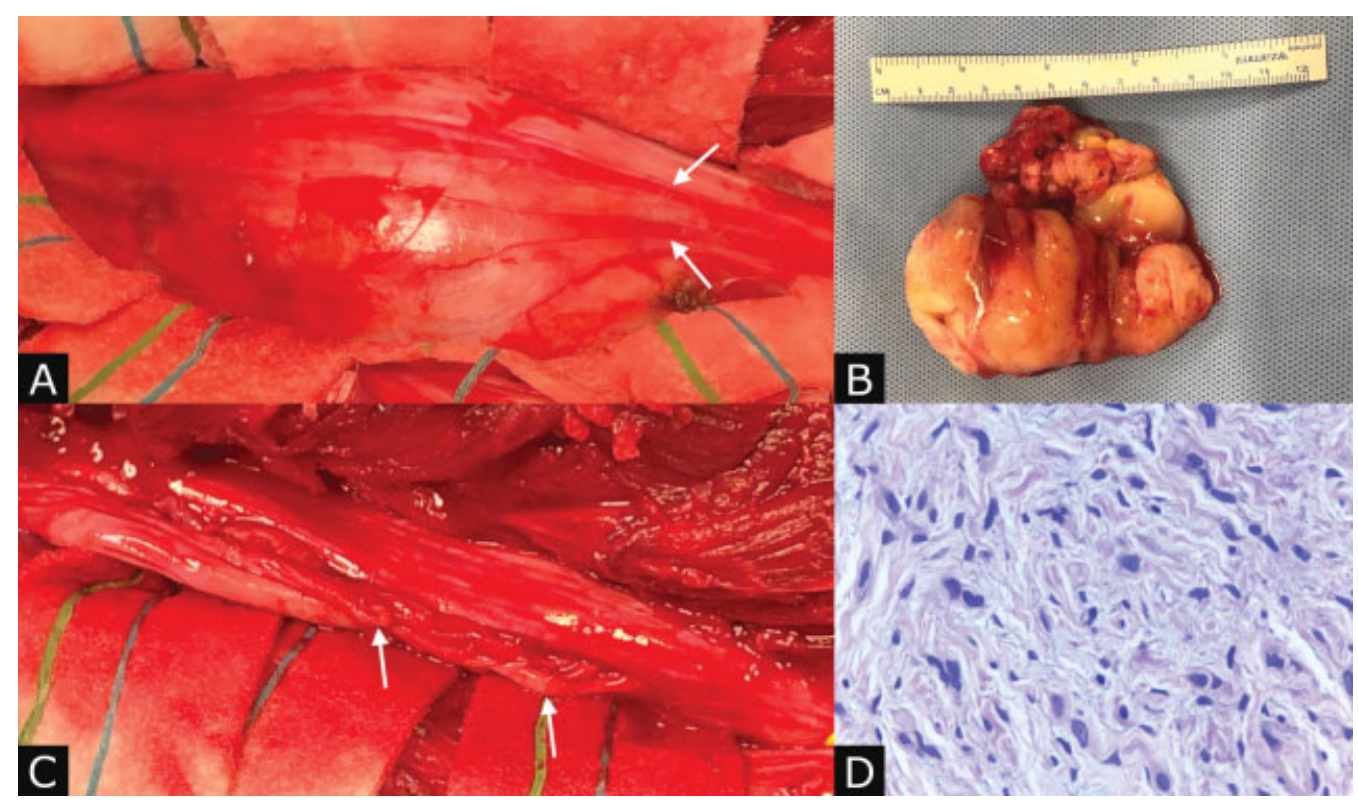

Fig. 4 (A) Exposure of the tumor. The arrows show functional fascicles dislocated by the mass. (B) Surgical aspect after resection of the lesion. The arrows show the preserved functional fascicles inside the tibial nerve. (C) Tumor resected en bloc. (D) Hematoxylin and eosin, 400x. Benign neurofibroma showing hypocellular proliferation of slightly elongated spindle cells, with wavy and hyperchromatic nuclei; in some, the nucleolus is evident. Collagen and a slight amount of mucoid material are observed among the neoplastic cells, as well as rare mononuclear inflammatory cells. The specimen presented no necrosis, and there were rare nuclear atypia. 
pain, so that pregabalin was discontinued. Six months after the surgery, the patient was also evaluated by vascular surgery, and no further episodes of DVT were observed.

\section{Discussion}

In the present study, we report a case of a patient with NF1 who experienced DVT due to compression of posterior tibial veins by a neurofibroma in the posterior compartment of the leg. To the best of our knowledge, the present is the first report of VT secondary to external compression by neurofibroma in the setting of NF1.

The prevalence of NF1 vasculopathy has been estimated to be of at least $8 \%$ in a study ${ }^{26}$ conducted with 181 pediatrics patients with NF1. Its mechanisms are yet not completely understood. $^{4,27-29}$ The vascular manifestations of NF1 appear to increase morbidity and mortality. A nationwide study ${ }^{30}$ conducted in the United States with death certificates showed that NF1 patients younger than 30 years of age who died were more than twice as likely to have been diagnosed with vascular disease when compared with those without NF.

The vasculopathy pathogenesis of NF1 has been shown to involve a series of events caused by dysfunction of the synthesis of neurofibromin (the encoded protein of the NF1 gene), which physiologically works as a downregulator of the Ras cascade signaling. Without the downregulation, the Ras signaling pathway augments cell proliferation in the vascular endothelium (with enhanced expression of cyclin D and cells more frequently entering the cell cycle). ${ }^{28}$ It also causes smooth-muscle hyperplasia ${ }^{7}$ and inflammation. ${ }^{29}$ The cell lineage that appears to be key in this pathogenesis is the bone-marrow-derived cell (BMDC). It has been shown that the inactivation of the NF1 gene in this cell lineage in mice was both sufficient and necessary to cause neointima formation and evidence of vascular inflammation similar to that observed in NF1 knockout mice. ${ }^{29}$

Although the manifestations of NF1 vasculopathy are mostly arterial, patients may also present with venous rupture, venous aneurysms, and/or VT. ${ }^{8-12,31}$ It has been shown that the absence of NF1 in vitro is sufficient for human venous endothelium cells to undergo autonomous proliferation. ${ }^{28}$ This endothelial dysfunction has been extensively implicated in the pathogenesis of VT. ${ }^{32-35}$ In this setting, the venous endothelium also shows altered vascular morphogenesis, which helps to explain the vascular morphological alterations in NF1 patients (that is, stenosis and aneurysms), 6,9,12,14,19,31 some of which may further increase the risk of VT (that is, venous aneurysm). ${ }^{36-38}$

We have found four reports of NF1 patients presenting with venous aneurysm and an associated VT. Seinturier et al. ${ }^{12}$ presented a case in which a 64-year-old woman, with NF1, developed pulmonary embolism secondary to a thrombosed venous femoral aneurysm. There are other 3 case reports of NF1 patients younger than 50 years of age who presented with internal jugular thrombosis secondary to aneurysmal degeneration. ${ }^{9,11,14}$

Lehrnbecher et al. ${ }^{8}$ reported a case in which a 4-year-old boy was diagnosed with NF1 systemic vasculopathy, including thrombosis of the right posterior tibial vein, without evidence of a correlated aneurysm or compression/infiltration by a tumor.

None of the seven reports described compression or infiltration of venous structures by a neurofibroma. Nonetheless, DVT in NF1 patients may also be caused via extrinsic compression by these tumors, as blood stasis has also been implicated in thrombogenesis. ${ }^{33,39}$ This, we think, contributed to the process of thrombogenesis in the present case, given that the tumor arose from the tibial nerve, in a tight region in the posterior compartment of the leg.

Deep vein thrombosis secondary to external compression by tumors has been reported in other settings such as the superior vena cava, and pulmonary and iliofemoral veins. ${ }^{40-42}$ It has been reported once in the setting of NF1, by an exostosis, in the popliteal vein. ${ }^{10}$ One study ${ }^{43}$ conducted with patients harboring high-grade non-Hodgkin lymphoma showed that venous compression by the tumor was present in $51 \%$ of patients with DVT. Given the higher prevalence of neurofibromas in NF1 patients, it is thus reasonable to assume that DVT secondary to tumoral compression may also have a higher prevalence in this population.

\section{Conclusion}

Clinicians should be alert to signs and symptoms suggestive of DVT in NF1 patients, as NF1 seems to favor venous endothelium dysfunction. Tumors may also compress or infiltrate the veins, promoting VT through blood stasis, when there is venous compression; or through endothelial damage, when infiltration occurs. In case there is a tumor compressing venous structures and promoting DVT, surgical resection with microsurgical techniques may be curative and able to preserve neurological function.

\section{Conflict of Interests}

The authors have no conflict of interests to declare.

\section{References}

1 Rosenbaum T, Wimmer K. Neurofibromatosis type 1 (NF1) and associated tumors. Klin Padiatr 2014;226(6-7):309-315

2 Friedman JM. Epidemiology of neurofibromatosis type 1. Am J Med Genet 1999;89(01):1-6

3 Uusitalo E, Leppävirta J, Koffert A, et al. Incidence and mortality of neurofibromatosis: a total population study in Finland. J Invest Dermatol 2015;135(03):904-906

4 Hirbe AC, Gutmann DH. Neurofibromatosis type 1: a multidisciplinary approach to care. Lancet Neurol 2014;13(08):834-843

5 Gutmann DH, Ferner RE, Listernick RH, Korf BR, Wolters PL, Johnson KJ. Neurofibromatosis type 1. Nat Rev Dis Primers 2017;3(01):17004

6 Oderich GS, Sullivan TM, Bower TC, et al. Vascular abnormalities in patients with neurofibromatosis syndrome type I: clinical spectrum, management, and results. J Vasc Surg 2007;46(03):475-484

7 Friedman JM, Arbiser J, Epstein JA, et al. Cardiovascular disease in neurofibromatosis 1: report of the NF1 Cardiovascular Task Force. Genet Med 2002;4(03):105-111

8 Lehrnbecher T, Gassel AM, Rauh V, Kirchner T, Huppertz HI. Neurofibromatosis presenting as a severe systemic vasculopathy. Eur J Pediatr 1994;153(02):107-109 
9 Belcastro M, Palleschi A, Trovato RA, Landini R, Di Bisceglie M, Natale A. A rare case of internal jugular vein aneurysmal degeneration in a type 1 neurofibromatosis complicated by potentially life-threatening thrombosis. J Vasc Surg 2011;54(04):1170-1173

10 Kwiatkowska W, Ferenc S, Romaszkiewicz P, et al. Deep vein thrombosis caused by an exostosis in an adolescent patient with peripheral neurofibromatosis type 1 . Vasa 2015;44(03): 233-236

11 Dova S, Ktenidis K, Karkos P, et al. A rare case of a spontaneous neck hematoma in a patient with type 1 neurofibromatosis. Auris Nasus Larynx 2016;43(05):591-594

12 Seinturier C, Blaise S, Thony F, Magne JL, Pernod G. A Femoral Common Vein Aneurysm in a Patient with Neurofibromatosis Syndrome Type 1. Ann Vasc Surg 2017;40:299.e7-299.e9

13 Mori F, Kawai M, Sato E, Igarishi S, Hikichi T, Yoshida A. Branch retinal vein occlusion in a Japanese patient with neurofibromatosis 1. Jpn J Ophthalmol 2001;45(06):634-635

14 Nopajaroonsri C, Lurie AA. Venous aneurysm, arterial dysplasia, and near-fatal hemorrhages in neurofibromatosis type 1. Hum Pathol 1996;27(09):982-985

15 Hiraki T, Higashi M, Goto Y, et al. A rare case of internal jugular vein aneurysm with massive hemorrhage in neurofibromatosis type 1. Cardiovasc Pathol 2014;23(04):244-247

16 Valdivia AR, Gandarias C. Neck Swelling in a Type 1 Neurofibromatosis Patient. Eur J Vasc Endovasc Surg 2019;58(03):414

17 Imahori T, Fujita A, Hosoda K, Kohmura E. Endovascular Internal Trapping of Ruptured Occipital Artery Pseudoaneurysm Associated with Occipital-Internal Jugular Vein Fistula in Neurofibromatosis Type 1. J Stroke Cerebrovasc Dis 2016;25(05):1284-1287

18 Bartline PB, McKellar SH, Kinikini DV. Resection of a Large Innominate Vein Aneurysm in a Patient with Neurofibromatosis Type 1. Ann Vasc Surg 2016;30:157.e1-157.e5

19 Jun YJ, Kim JM, Kim JA, Lee JH, Kim SM, Kim YJ. Venous malformation associated with type 1 neurofibromatosis: a case report. ANZ J Surg 2017;87(11):945-946

20 De Caridi G, Massara M, Spinelli F. Uncommon case of symptomatic left renal vein compression caused by neurofibroma. Asian Cardiovasc Thorac Ann 2016;24(05):492-492

21 Ku Y-K, Chen H-W, Chen H-W, Fu C-J, Chin S-C, Liu Y-C. Giant extracranial aneurysms of both internal carotid arteries with aberrant jugular veins in a patient with neurofibromatosis type 1. AJNR Am J Neuroradiol 2008;29(09):1750-1752

22 Hinsch N, Kriener S, Ritter R-G, Holzer K. Fatal haemorrhage due to extensive fragility of medium- and large-sized arteries and veins in a young patient with neurofibromatosis 1. Cardiovasc Pathol 2008; 17(02):108-112

23 Zaret CR, Choromokos EA, Meisler DM. Cilio-optic vein associated with phakomatosis. Ophthalmology 1980;87(04):330-336

24 Wasa J, Nishida Y, Tsukushi S, et al. MRI features in the differentiation of malignant peripheral nerve sheath tumors and neurofibromas. AJR Am J Roentgenol 2010;194(06):1568-1574

25 Ahlawat S, Blakeley JO, Rodriguez FJ, Fayad LM. Imaging biomarkers for malignant peripheral nerve sheath tumors in neurofibromatosis type 1. Neurology 2019;93(11):e1076-e1084
26 Kaas B, Huisman TAGM, Tekes A, Bergner A, Blakeley JO, Jordan LC. Spectrum and prevalence of vasculopathy in pediatric neurofibromatosis type 1. J Child Neurol 2013;28(05):561-569

27 Lin AE, Birch PH, Korf BR, et al. Cardiovascular malformations and other cardiovascular abnormalities in neurofibromatosis 1 . Am J Med Genet 2000;95(02):108-117

28 Bajaj A, Li Q, Zheng Q Pumiglia K. Loss of NF1 Expression in Human Endothelial Cells Promotes Autonomous Proliferation and Altered Vascular Morphogenesis. Pizzo SV, editor. PLoS One 2012; 7(11):e49222

29 Lasater EA, Li F, Bessler WK, et al. Genetic and cellular evidence of vascular inflammation in neurofibromin-deficient mice and humans. J Clin Invest 2010;120(03):859-870

30 Rasmussen SA, Yang Q, Friedman JM. Mortality in neurofibromatosis 1: an analysis using U.S. death certificates. Am J Hum Genet 2001;68(05):1110-1118

31 Delvecchio K, Moghul F, Patel B, Seman S. Surgical resection of rare internal jugular vein aneurysm in neurofibromatosis type 1 . World J Clin Cases 2017;5(12):419-422

32 Blann AD. How a damaged blood vessel wall contibutes to thrombosis and hypertenasion. Pathophysiol Haemost Thromb 2003;33(5-6):445-448

33 Mackman N. New insights into the mechanisms of venous thrombosis. J Clin Invest 2012;122(07):2331-2336

34 Poredos P, Jezovnik MK. Endothelial Dysfunction and Venous Thrombosis. Angiology 2018;69(07):564-567

35 Wang M, Hao H, Leeper NJ, Zhu LEarly Career Committee. Thrombotic Regulation From the Endothelial Cell Perspectives. Arterioscler Thromb Vasc Biol 2018;38(06):e90-e95https://www. ahajournals.org/doi/10.1161/atvbaha.118.310367 [Internet]

36 Chahlaoui J, Julien M, Nadeau P, Bruneau L, Roy P, Sylvestre J. Popliteal venous aneurysm: a source of pulmonary embolism. AJR Am J Roentgenol 1981;136(02):415-416

37 Calligaro KD, Ahmad S, Dandora R, et al. Venous aneurysms: surgical indications and review of the literature. Surgery 1995; 117(01):1-6

38 Gillespie DL, Villavicencio JL, Gallagher C, et al. Presentation and management of venous aneurysms. J Vasc Surg 1997;26(05): 845-852

39 Esmon CT. Basic mechanisms and pathogenesis of venous thrombosis. Blood Rev 2009;23(05):225-229

40 Liaw C-C, Chang H, Yang T-S, Wen M-S. Pulmonary Venous Obstruction in Cancer Patients. J Oncol 2015;2015:210916

41 Liao T-Y, Hsu H-C, Wen M-S, Juan Y-H, Hung Y-H, Liaw C-C. Iliofemoral Venous Thrombosis Mainly Related to Iliofemoral Venous Obstruction by External Tumor Compression in Cancer Patients. Case Rep Oncol 2016;9(03):760-771

42 Friedman T, Quencer KB, Kishore SA, Winokur RS, Madoff DC. Malignant Venous Obstruction: Superior Vena Cava Syndrome and Beyond. Semin Intervent Radiol 2017;34(04):398-408

43 Ottinger H, Belka C, Kozole G, et al. Deep venous thrombosis and pulmonary artery embolism in high-grade non Hodgkin's lymphoma: incidence, causes and prognostic relevance. Eur J Haematol 1995;54(03):186-194 